\title{
SEPARATION AGREEMENTS: THEIR FUNCTION AND FUTURE
}

\author{
Harriet F. Pilped* and Theodora S. Zavin $\dagger$
}

In theory, in the United States today divorce can be obtained only as the result of a court fight. Whether or not one spouse can divorce the other is supposed to depend on the outcome of an adversary proceeding designed to establish the "guilt" or "innocence" of the defendant. If he is "guilty" of one of the grounds specified by the law of the particular state as a cause for divorce, and if the other party has not been "guilty" of that or any other ground so specified, a divorce decree follows, it being assumed that the divorce is an appropriate punishment for the wrongdoing defendant.

Actually the elaborate legal superstructure doesn't work this way at all. Its chief accomplishment has been to make most divorce a semi-bootleg affair in which ordinarily only a small and relatively unimportant part of the total picture ever gets into court. The emphasis on an adversary determination of questions of guilt and innocence (usually completely unrelated to the real marital difficulty), and the absence in most parts of the country of any judicial machinery capable of surveying a total marital picture, have resulted in a situation where the court rules on the technicalities of the divorce while the essential questions are settled by the parties extra-judicially, usually by negotiating and entering into a contract known as a separation agreement.

In a typical case recently tried before an official Referee in New York City, ten minutes was spent in establishing the "adultery" of the husband and the proper service of the complaint. The Referee then addressed a question to the wife as to the future custody of the child of the marriage and was told that the parties had entered into a separation agreement providing that the wife was to have custody of the child and that the husband was to contribute $\$ 5$ a week for the child's support. The Referee then asked the husband's income and whether he had been paying the $\$ 15$ a week regularly. Upon hearing the witness' answers to these questions, the

* B.A. I932, Vassar College; M.A. 1933, LL.B. 1936, Columbia University. Chairman, Legal Committec, American Association of Marriage Counselors; Chairman, Legal Committee, National Council on Family Relations; Member, Citizens Committee for the Improvement of Divorce Laws, sponsored by the Association of the Bar of the City of New York. Member of the law firm of Greenbaum, Wolff \& Ernst, New York, N. Y. Co-author [with Theodora S. Zavin] of Your Marriage and the Law (1952).

† A.B. I941, Hunter College; LL.B. 1943, Columbia Law School; Decisions Editor, Columbia Law Review. Staff Attorney to late Honorable George Z. Medalie, r943-r944. Associated with Greenbaum, Wolff and Ernst, 1944-1950, specializing in marriage and family law and in legal aspects of literary property. Presently Staff Counsel to Broadcast Music, Inc. Co-author (with Harriet F. Pilpel) of Your MarRiage and the LAW (1952). 
Referee offered his own opinion that the sum was too high and then promptly called the next case. The total time allocated in the hearing to such basic questions as custody and support was about one and one half minutes.

Ordinarily, unless the terms of a separation agreement are blatantly outrageous or the agreement itself is a result of fraud, overreaching or duress, the courts tend to accept whatever arrangements have been made by the parties in the agreement. The terms of the agreement become the terms of the court's decree without any real examination by the court of the factors which were considered in fixing its terms. Among the sixty-four dollar questions not asked by the Referee in the case referred to were: Did the wife have any potential earning capacity of her own? Did the wife have a friend or relative who would care for the child in the event she took a job, or would she have to allocate part of her income for such care? Did the husband have any capital or any source of income other than the salary which was mentioned? Were the wife's parents willing and able to contribute to the support of their daughter and grandchild by giving them a place to live or any other assistance? Were the child's best interests served by giving custody to the mother? Had suitable arrangements been made for a sound continuing relationship between the child and the father?

In theory no divorce can be obtained in this country simply by virtue of the fact that the parties decide to get a divorce except in those few states where the voluntary separation of the couple for a given period of years is in itself ground for divorce. ${ }^{1}$ In practice, we are aware that over $9^{\circ}$ per cent of all divorces are uncontested, ${ }^{2}$ which means that the basic terms are set by agreement and the divorce then obtained on the most innocuous grounds specified by the applicable state law. In many cases the state's laws are such that the procurement of a divorce with the cooperation of both spouses is ridiculously easy, while, on the other hand, in the absence of such cooperation it may be difficult, if not impossible, to bring about the dissolution of even a hopeless marriage. Here again, New York, the state with the strictest laws on divorce, serves to illustrate. Arranging a hotel room "adultery" is a relatively simple matter providing the defendant is cooperative enough to provide the plaintiff or her attorney (chivalry appears in most cases to require that the wife be the plaintiff, no matter what the grounds) with due notice of the time when and place where the evidence will be available. In a case of true adultery where the adulterous spouse is not willing to cooperate, the plaintiff may have to spend hundreds of dollars to hire investigators to watch the defendant until such time as he permits himself to be caught in a compromising situation. If the adulterer is sufficiently circumspect, the spouse may never be able to prove the adultery although it may have gone on for years. Annulment actions which have become very popular

\footnotetext{
${ }^{1}$ Typical of such statutes are the following: Arrz. Code ANv. \$27-802 (1939); Md. ANv. Code art. I6, \$40 (1947); Nev. Comp. Laws Ann. \$9467.06 (I947); Tex. Rev. Civ. Stat. AnN. art. 4629 (I951); WIs. Stat. $\$ 247.07$ (1947). See Note, Separation for a Period of Years as Grounds for Divorce, 97 U. on PA. I. Rev. 705 (1949).

2See Alexander, The Follies of Divorce: A Therapeutic Approach to the Problem, 36 A. B. A. J. 105, 107 (1950); Note, Lavv and the Disrupted Marriage, 35 Mins. L. Rev. 168, 169, 172 (1951).
} 
in New York are likewise easy to obtain with cooperation and difficult otherwise. For a valid out-of-state divorce the cooperation of the defendant is even more essential if the divorce is to have any effect or validity outside the state where it is granted.

The necessity in practical terms for the defendant's cooperation if a valid divorce or annulment decree is to be obtained, results in the introduction of factors in the negotiation of a separation agreement which have little to do with the equities of the situation or with the future well-being of the members of the family. The amount of support is frequently determined, not by the evaluation of relevant social and economic factors alone, but by the comparative eagerness of the spouses to dissolve the marriage. Where the husband is the one who badly wants the divorce, the amount of alimony fixed by the separation agreement is apt to be more than a court would allow the wife if the question were left for judicial determination. The increased support is the price the husband pays for his wife's cooperation in securing the decree. Conversely, where the wife is more eager for the divorce, the amount given her by the separation agreement is often just as little as the husband's attorney feels she can be given without having the court question the validity of the agreement. The custody of children may likewise be bargained either in terms of increased or decreased alimony or in terms of the willingness of one spouse to consent to the divorce.

In some few cases where the party having the stronger bargaining position has overplayed his hand or where the attorneys who drew the separation agreement have been unskilled in their attempts to clothe extraordinarily harsh terms with a reasonable air, the courts have refused to approve the agreements. ${ }^{3}$ For the most part, however, the courts have ceased to exercise any real function in determining support and custody except in that small minority of cases where the parties have been unable to reach an agreement. Even in such cases the decision of the court is often used, not as a final determination of the issues, but as a basis for further negotiations by the parties.

None of this is to be construed as a plea for stricter supervision of separation agreements by the courts at this time. So long as the courts are ill equipped, or not equipped at all, to handle questions of custody, support, and the like, the parties are well advised to settle such questions for themselves by negotiation.

In many states the courts are obliged by statute in fixing custody and support, to do so in terms of the "guilt" or "innocence" of the parties4-a concept completely unrelated to their economic needs and assets or their prospects for healthy readjustment after the dissolution of the marriage. Furthermore, few of our courts are staffed with the trained personnel required to aid a judge in intelligent planning for the family as a whole. Nor is the character of adversary litigation or the hurried atmosphere of a court burdened with an already crowded calendar con-

${ }^{3}$ See, e.g., Yates v. Yates, 5 I N. Y. S. (2d) 135 (Sup. Ct. I944).

-E.g., Ore. Comp. Laws Ann. \$9-914 (I940); Mass. Ann. Laws c. 208, \$27 (1933); Maine Rev. STAT. C. 153, \$62 (1944). 
ducive to any kind of sound evaluation of the resources-financial and otherwiseor needs, of the various members of a family. The Interprofessional Commission on Marriage and Divorce, headed by Judge Paul Alexander of the Toledo, Ohio Family Court, envisages a judicial machinery which will meet the necessities of a disintegrating family group. As Judge Alexander and the other proponents of the Commission's "Family Court" point out, diagnosis and therapy will be substituted for guilt and punishment. ${ }^{5}$ Even where therapy is not possible, i.e., where the investigative and reconciliatory services of the Family Court and its trained personnel do not succeed in keeping the family intact, the knowledge gained of the problems of the individual family will provide an invaluable background for the court when the time comes for fixing the terms of a final separation or divorce.

At this moment, however, only a few courts, widely seattered over the country, are performing or can perform any real function in planning the future of a disrupted family unit. The burden of providing conscientious and intelligent help for the family, therefore, tends to fall on the lawyers in the majority of cases where the spouses have agreed only to disagree. The lawyer today is, unfortunately, often ill-prepared to shoulder this responsibility. Until such time as the help of marriage counselors becomes a routine matter in every matrimonial case or the family court with its staff of trained experts is easily available, the lawyer's task in divorce, annulment, and separation cases is an extraordinarily complex one, calling for skills which have little to do with the contents of statute and case books. Lawyers called upon to negotiate the terms of a separation are dealing, not primarily with legal problems, but with psychological, social and economic questions as well. Not infrequently the lawyer enters the picture at a time when both spouses are emotionally disturbed; contrary to popular belief, most people do not reach the point of breaking up their homes and marriages lightly or painlessly. This is, of course, especially true where there are children. By the time the spouses reach the point of enlisting legal aid, they are often bitter and vindictive. It is easy for an attorney under these circumstances to restrict his role in the situation to pure advocacy and to adopt as his aim the same goal which he might set for himself in representing a client in a commercial breach of contract case-in other words, to get as much for his client as he can if he represents the wife, and to handle the case in such a way that the whole affair will put his client as little out of pocket as possible if he is acting as the husband's counsel. In the long run, this limited view of the lawyer's function in matrimonial matters will not benefit even his own client. A separation agreement does not settle a matter forever in the same sense that a satisfaction wipes out a mortgage. The husband, wife, and the children will be living under the terms of the separation agreement for many years, perhaps a lifetime. Unless the agreement is sound from the long range viewpoint of the entire family, it is likely to increase hostility between the spouses and destroy the

'Alexander, The Follies of Divorce, supra note 2, at 168-170; also, by the same author, What is $A$ Family Court, Anyway?, 26 Cons. B. J. 243 (Sept. 1952). 
chances of that decent relationship developing between the children and both their parents which all experts agree is important to their well-being. If the agreement is really unworkable in practical terms, one party or the other will eventually succeed in destroying it. The whole process then has to be gone through again, usually with no net gain to anyone.

The lawyer's first job should be that of helping his client to see the family situation in perspective. He must have both the initiative and the ability to dissuade his client from using the separation agreement as a weapon for punishing the other spouse. Conversely, he must act as a brake when his client's feelings of guilt concerning the break-up are so great that the client is eager to give or concede more than he should. On the other hand, the lawyer should be familiar with the marriage counseling agencies that exist in his area so that he can promptly refer clients willing to seek such help. And he should be trained to recognize the symptoms that call for the intervention of other experts: doctors, psychiatrists, clergymen, and the like.

In addition to all the psychological aspects of the lawyer's task, he must also have some training and experience in evaluating economic realities; in many cases his is the only expert guidance available when a family which has been living comfortably together on its income is called upon to divide the same income between two independent households.

In a very real sense, the children are and should be the real clients in any divorce suit. And here too the lawyer should be well trained. The wise lawyer knows the pros and cons of splitting their custody, realizes that for a while at least the children's greatest security may lie in each other, recognizes that children need to be close to both their parents, not only the one having their custody, and has an awareness of a host of other factors which are involved whenever a husband and wife separate. Above all, the lawyer can be of inestimable value at this crucial stage if he can help the parents to see the folly of using the children as weapons against each other or attempting to make the children side with one parent.

Beyond all of this, the conscientious lawyer has a duty to explore the possibility of saving the marriage. While the laws of many states specifically impose this duty on the court having jurisdiction of the divorce suit, ${ }^{6}$ few courts actually have any constructive program-or any facilities-for the reconciliation of warring spouses. Mending a marriage takes more than a cursory exhortation from the bench to "try again" or "consider your children." It requires a careful examination into the true causes of the difficulty, causes which the parties themselves often do not consciously recognize, and the careful evolution of a new and improved relationship. This kind of help can be offered by the type of Family Court previously referred to and has been markedly successful in those few courts in the United States which are geared to offer troubled couples more than shibboleths about the sanctity of marriage. ${ }^{7}$ In areas not served by such courts, the duty of exploring

'See, e.g., S. C. Laws 1949, No. I37, §6.

' See Note, Law and the Disrupted Marriage, supra note 2, at 169, I83. 
the possibilities of reconciliation really falls upon the lawyer. The lawyers for the parties are apt to be the only outsiders who ever have any connection with a breaking family, and their counsel and guidance therefore assume a very special importance. All the other "advisers"-mothers, fathers, sisters, brothers, and friends -are apt to "take sides" and be as violently partisan as the particular spouse they are backing, with no real ability to view the situation in perspective or as a whole.

The average lawyer's training for all of these responsibilities is, at best, haphazard; at worst, nonexistent. In most law schools the teaching of even the law of domestic relations is restricted to a one semester optional course. ${ }^{8}$ This is barely time, particularly in those law schools which attempt to teach more than the law of the state in which the school is located, to cover the statutes and case material which form the basis of the legal knowledge which the prospective lawyer needs. Training in the nature of matrimonial problems and techniques of handling them is virtually unknown. The lawyer must, therefore, look to his non-legal education, to what guidance he can obtain from older lawyers, and to his own experience as husband or wife and parent. The chances are that no matter how good his intentions, his limited personal experience will be insufficient to equip him to handle. the complicated human problems he will encounter in the domestic relations field.

There is a very real and immediate need to help lawyers fulfill the responsibilities which will continue to be theirs in this field, at least until the Family Court becomes a reality throughout the country. By any realistic standard, family reorganization is as vital a problem as any lawyer is likely to undertake and should be recognized as such by legal educators, by bar associations, and by all others concerned with the wise and competent functioning of the practicing lawyer. If it is once so recognized, we may hope, not only for better trained lawyers, but also for the gradual development of a body of shared learning on the technique of handling matrimonial disputes. Perhaps if our law schools come to regard Family Reorganization as having as much significance as Corporate Reorganization, the practicing lawyers of the future will be able to discharge their duty to matrimonial clients and to society with something more than a hope and a prayer to guide them.

See Bradway, The Myth of the Innocent Spotise, in Selected Readings on Family Law 937, 951 (1950), for an interesting analysis of the scope of training in the law of Domestic Relations in the typical law school. 